\title{
Can regional variation in "avoidable" mortality be explained by deaths outside hospital? A study from Sweden, 1987-90
}

\author{
Ragnar Westerling
}

\begin{abstract}
Study objective - This study aimed to calculate the proportion of deaths outside hospital in Sweden for some conditions for which the acute medical management may be important to the outcome and to analyse whether the proportion of deaths outside hospital can explain regional variations in mortality from these causes of death.

Design - The place of death was registered on all death certificates in Sweden during the period 1987-90. The proportion of deaths outside hospital was calculated at the national level for selected causes of death. Variation in cause-specific mortality among the 26 administrative health areas in Sweden was analysed. Death rate ratios were calculated with standardisation for age and sex using the national rate as standard. The correlation between the proportion of deaths outside hospital in each health area and the cause specific mortality irrespective of place of death was calculated. For areas with a significantly high death rate the ratios for mortality outside hospital as well as in hospital were analysed in order to decide which component of mortality represented a high mortality risk.
\end{abstract}

Setting and participants - All death registration in Swedish citizens and other residents in Sweden aged under 70 years between 1987 and 1990 which gave diabetes, asthma, ischaemic heart disease, cerebrovascular diseases, or ulcer of the stomach or duodenum as the underlying cause of death.

Main results - For asthma (58\%) and ischaemic heart disease (54\%), most deaths occurred outside hospital. For most causes of death, however, no correlation was found among the health areas between the proportion of deaths outside hospital and the SMR for mortality irrespective of the place of death. A high death rate was associated with a high proportion of deaths outside hospital, for diabetes in one area in the north of Sweden (Norrbotten) and for ulcer of the stomach and duodenum in one large municipality (Göteborg).

Conclusions - The high proportion of deaths outside hospital at the national level for some of the conditions studied suggests that in-depth studies of the process preceding death and the functioning of medical care are needed. In most cases, however, no evidence was found that regional variation in mortality could be explained by death outside hospital. The results for diabetes in Norbotten and ulcer of stomach and duodenum in Göteborg indicate that in-depth studies on the quality of care are required.

( $(\mathcal{F}$ Epidemiol Community Health 1996;50:326-333)

The concept of studying "avoidable" mortality as an indicator of the outcome of health care has been used in many studies from different countries. ${ }^{1-5}$ The idea is that high death rates for conditions for which health services may influence mortality outcome is a warning signal that in-depth studies on the quality of care are needed. Several causes of death have been used as indicators of avoidable mortality and for a number of these the type of intervention and the health services responsible for the intervention have been defined. ${ }^{1-3}$ Several studies of regional variation in avoidable mortality have been performed showing regional variation for avoidable death indicators in many countries. ${ }^{4-12}$

For some conditions, such as asthma, diabetes, and ischaemic heart disease the acute management of the disorder is of special importance. In such cases, access to acute hospital care may influence the outcome. Studies of the process preceding death have indicated that a delay in seeking or receiving medical care may have influenced death from asthma and diabetes. ${ }^{13-20}$ For some conditions such as ischaemic heart disease ${ }^{2-24}$ and perforated peptic ulcer, ${ }^{21}$ early arrival at hospital and early start of acute treatment have been found to improve the survival rate.

A proportion of deaths outside hospital may thus potentially influence the death rate for some conditions usually treated in hospital in the acute phase of the disease. This was the case in a study of ischaemic heart disease from three areas of Australia and New Zealand where a higher case fatality rate was associated with a higher rate of deaths outside hospital. ${ }^{25}$ Thus, a high death rate associated with a high proportion of deaths outside hospital may be a "sentinel" health event which in accordance with the avoidable mortality concept indicates that in-depth studies on the quality of care are needed.

This study aimed to calculate the proportions of deaths outside hospital in Sweden for some conditions where the acute management of 
Table 1 The mean population in Sweden aged 0-69 years in relation to Swedish administrative health areas, 1987-90

\begin{tabular}{lr}
\hline Administrative health area & Population \\
\hline 1 Stockholm & 1464332 \\
2 Uppsala & 236468 \\
3 Södermanland & 223428 \\
4 Östergötland & 352069 \\
5 Jönköping & 267932 \\
6 Kronoberg & 154494 \\
7 Kalmar & 206964 \\
8 Gotland & 49959 \\
9 Blekinge & 131071 \\
10 Kristianstad & 248617 \\
11 Malmöhus & 476292 \\
12 Malmö (municipality) & 199839 \\
13 Halland & 220652 \\
14 Göteborg and Bohus & 270226 \\
15 Göteborg (municipality) & 379497 \\
16 Älvsborg & 384433 \\
17 Skaraborg & 240295 \\
18 Värmland & 245458 \\
20 Örebro & 236312 \\
21 Köstmanland & 228488 \\
22 Gävleborg & 248983 \\
23 Västernorrland & 251641 \\
24 Jämtland & 227988 \\
25 Västerbotten & 116606 \\
26 Norrbotten & 222541 \\
Total & 237098 \\
\hline
\end{tabular}

the disease may be important and to analyse whether the proportions of deaths outside hospital for these conditions influences regional variation in cause specific mortality.

\section{Methods}

The Swedish cause of death register is based on the death certificates signed by the physician for all deaths among Swedish citizens and other persons resident in Sweden. The death certificates include information on the causes of death, one of which is defined as the underlying cause of death following international classification rules. ${ }^{26}$ The death certificates are scrutinised and registered at the National Central Bureau of Statistics. Specific procedures and coding rules have been developed in order to assure the quality of the data. ${ }^{27}$

During the years 1987-90 the death certificates also included information on the place of death. These data were coded at the National Central Bureau of Statistics and were registered in the data base together with the cause of death. From the cause of death register data it was possible to decide whether the deaths had occurred in hospital or outside hospital.

For this study, data on the underlying cause of death and the place of death were collected by age, sex, and health administrative area between 1987 and 1990. In Sweden health and medical care is the responsibility of 26 health administrative areas ( 23 county councils and 3 municipalities) and these areas (number of areas $\mathrm{k}=26$ ) were used in the analyses (table 1; fig 1).

Analyses were performed for the five causes of death: diabetes, ischaemic heart disease, cerbrovascular disease, asthma, and ulcer of the stomach and duodenum. These causes of death have been found to be common enough to perform analyses of regional variation in Sweden. ${ }^{5}$ Analyses were restricted to ages 0-69 years. In this age group, all Swedish deaths from the five causes were included in the analyses

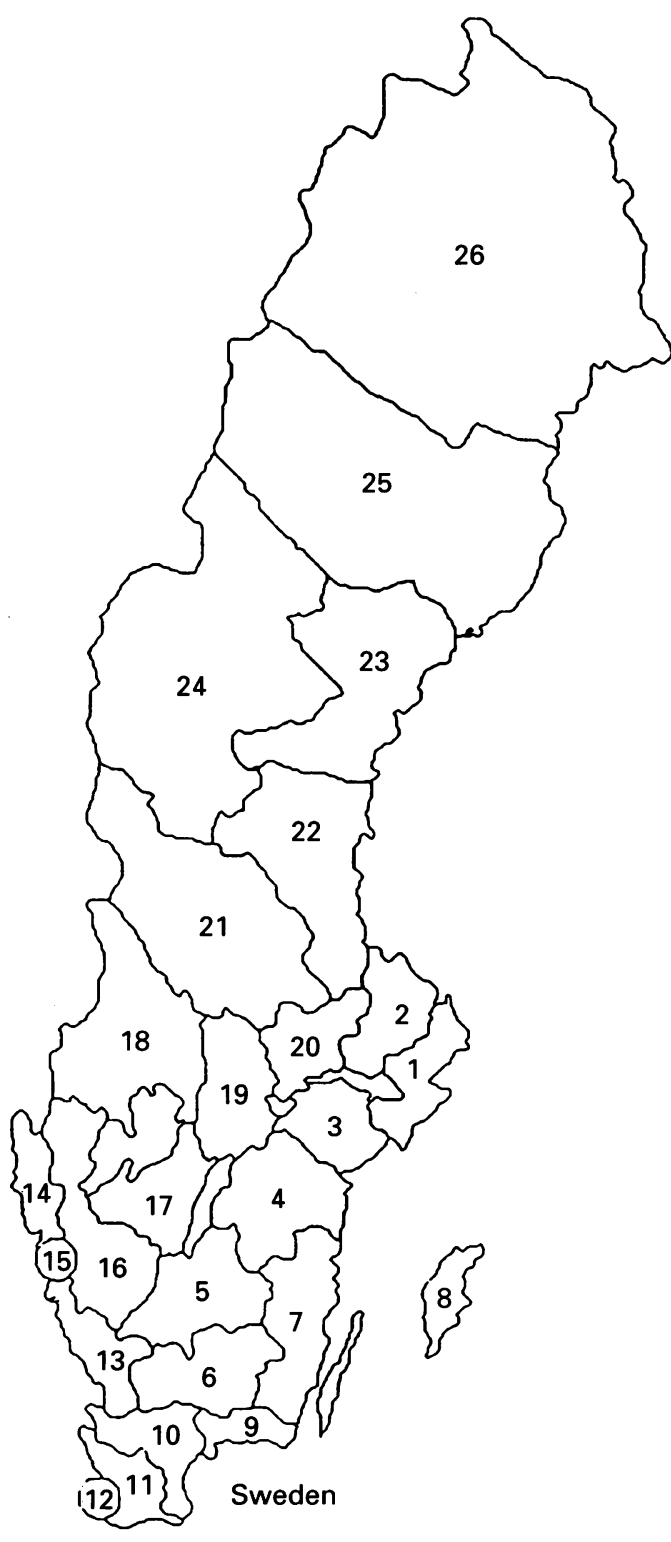

Figure 1 The 26 administrative health areas in Sweden between 1987 and 1990. (Numbers of the areas according to table 1).

without any further selection. The number of deaths and the mean annual death rate were calculated for each cause of death. Analyses were performed for deaths in hospital, deaths outside hospital, death with unknown place of death as well as for total numbers of deaths. The proportion of deaths outside hospital was calculated for each cause of death. The autopsy rate was calculated for deaths in hospital and deaths outside hospital respectively based on the notifications on the death certificates.

The age and sex distribution of the population differed between the different health areas. ${ }^{28}$ In order to compare the mortality in administrative health areas, direct standardisation for age and sex was performed (five year age groups). ${ }^{29}$ (Direct and indirect standardisation gave equal results.)

The null hypothesis that there was no variation among the areas - that is, that all area death rates were equal to the national standard, was tested using a $\chi^{2}$ analysis $(\mathrm{df}=\mathrm{k}-1=$ $25)(5,30,31)$. 
Table 2 The number of deaths and the mean annual death rate* for selected causes of death in people aged 0-69 years in Sweden between 1987 and 1990 in relation to place of death

\begin{tabular}{|c|c|c|c|c|c|c|c|c|c|c|}
\hline$I C D-9$ code & Cause of death & $\begin{array}{l}\text { No. of } \\
\text { deaths in } \\
\text { hospital }\end{array}$ & $\begin{array}{l}\text { Death } \\
\text { rate in } \\
\text { hospital }\end{array}$ & $\begin{array}{l}\text { No. of deaths } \\
\text { outside } \\
\text { hospital }\end{array}$ & $\begin{array}{l}\text { Death rate } \\
\text { outside } \\
\text { hospital }\end{array}$ & $\begin{array}{l}\text { No. of } \\
\text { deaths place } \\
\text { unspecified }\end{array}$ & $\begin{array}{l}\text { Death } \\
\text { rate place } \\
\text { unspecified }\end{array}$ & $\begin{array}{l}\text { No. of } \\
\text { deaths } \\
\text { total }\end{array}$ & $\begin{array}{l}\text { Death } \\
\text { rate } \\
\text { total }\end{array}$ & $\begin{array}{l}\text { Proportion of } \\
\text { deaths outside } \\
\text { hospital }\end{array}$ \\
\hline $\begin{array}{l}250 \\
410-414 \\
430-438 \\
493 \\
531-534\end{array}$ & $\begin{array}{l}\text { Diabetes } \\
\text { Ischaemic heart disease } \\
\text { Cerebrovascular disease } \\
\text { Asthma } \\
\text { Ulcer of stomach and } \\
\text { duodenum }\end{array}$ & $\begin{array}{r}924 \\
9779 \\
4095 \\
271 \\
246\end{array}$ & $\begin{array}{r}3.07 \\
32.50 \\
13.61 \\
0.90 \\
0.82\end{array}$ & $\begin{array}{r}419 \\
12048 \\
679 \\
400 \\
199\end{array}$ & $\begin{array}{r}1 \cdot 39 \\
40 \cdot 04 \\
2.26 \\
1.33 \\
0.66\end{array}$ & $\begin{array}{r}22 \\
583 \\
98 \\
21 \\
7\end{array}$ & $\begin{array}{l}0.07 \\
1.94 \\
0.32 \\
0.07 \\
0.02\end{array}$ & $\begin{array}{r}1365 \\
22410 \\
4872 \\
692 \\
452\end{array}$ & $\begin{array}{r}4 \cdot 54 \\
74 \cdot 48 \\
16 \cdot 19 \\
2 \cdot 30 \\
1 \cdot 50\end{array}$ & $\begin{array}{l}0.31 \\
0.54 \\
0 \cdot 16 \\
0.58 \\
0 \cdot 44\end{array}$ \\
\hline
\end{tabular}

* Number of deaths per 100000 population

Table 3 The number of deaths and the proportion of deaths followed by autopsy for selected causes of death in people aged 0-69 years in Sweden between 1987 and 1990 in relation to place of death

\begin{tabular}{|c|c|c|c|c|c|c|c|c|c|c|}
\hline$I C D-9$ code & Cause of death & $\begin{array}{l}\text { No. of } \\
\text { deaths in } \\
\text { hospital }\end{array}$ & $\begin{array}{l}\text { No. of deaths } \\
\text { in hospital } \\
\text { with autopsy }\end{array}$ & $\begin{array}{l}\text { Proportion } \\
\text { of deaths in } \\
\text { hospital with } \\
\text { an autopsy }\end{array}$ & $\begin{array}{l}\text { No. of } \\
\text { deaths } \\
\text { outside } \\
\text { hospital }\end{array}$ & $\begin{array}{l}\text { No. of deaths } \\
\text { outside hospital } \\
\text { with autopsy }\end{array}$ & $\begin{array}{l}\text { Proportion of } \\
\text { deaths outside } \\
\text { hospital with } \\
\text { autopsy }\end{array}$ & $\begin{array}{l}\text { Total } \\
\text { no. of } \\
\text { deaths }\end{array}$ & $\begin{array}{l}\text { Total no. of } \\
\text { deaths with } \\
\text { autopsy }\end{array}$ & $\begin{array}{l}\text { Proportion of } \\
\text { deaths with } \\
\text { autopsy }\end{array}$ \\
\hline $\begin{array}{l}250 \\
410-414\end{array}$ & $\begin{array}{l}\text { Diabetes } \\
\text { Ischaemic heart } \\
\text { disease }\end{array}$ & $\begin{array}{r}924 \\
9779\end{array}$ & $\begin{array}{r}309 \\
5139\end{array}$ & $\begin{array}{l}0.33 \\
0.47\end{array}$ & $\begin{array}{r}419 \\
12048\end{array}$ & $\begin{array}{r}212 \\
9002\end{array}$ & $\begin{array}{l}0.51 \\
0.75\end{array}$ & $\begin{array}{r}1365 \\
22410\end{array}$ & $\begin{array}{r}525 \\
13765\end{array}$ & $\begin{array}{l}0.38 \\
0.61\end{array}$ \\
\hline $430-438$ & $\begin{array}{l}\text { Cerebrovascular } \\
\text { disease }\end{array}$ & 4095 & 1168 & $0 \cdot 28$ & 679 & 576 & $0 \cdot 85$ & 4872 & 1756 & $0 \cdot 36$ \\
\hline $\begin{array}{l}493 \\
531-534\end{array}$ & $\begin{array}{l}\text { Asthma } \\
\text { Ulcer of stomach } \\
\text { and duodenum }\end{array}$ & $\begin{array}{l}271 \\
246\end{array}$ & $\begin{array}{r}92 \\
162\end{array}$ & $\begin{array}{l}0.34 \\
0.66\end{array}$ & $\begin{array}{l}400 \\
199\end{array}$ & $\begin{array}{l}307 \\
191\end{array}$ & $\begin{array}{l}0.77 \\
0.96\end{array}$ & $\begin{array}{l}692 \\
452\end{array}$ & $\begin{array}{l}404 \\
355\end{array}$ & $\begin{array}{l}0.58 \\
0.78\end{array}$ \\
\hline
\end{tabular}

The level of the observed variance was calculated by dividing the $\chi^{2}$ values by the total number of deaths (n) in Sweden for each cause of death. When there are small numbers of deaths, random factors may have a considerable impact on the variation. Therefore, methods have been developed for studies of so-called small area variation in order to take into account the influence of the expected random variation. ${ }^{53132}$. The observed variance can be divided into two components, the random component and the systematic (non-random) component.

When the null hypothesis is true all the observed variations are due to random variation. Assuming the null hypothesis, the mathematical expectation of the $\chi^{2}$ distribution is the degree of freedom of the distribution. Therefore the random component of the variation was estimated as the number of the degree of freedom $(k-1)$ of the $\chi^{2}$ distribution divided by the total number of deaths. The systematic (non-random) component of variation was estimated as the observed variance minus the random variance, that is:

$$
\sum_{i=1}^{k} \frac{\left(o_{1}-e_{i}\right)^{2} / e_{i}}{n}-\frac{(k-1)}{n}
$$

where $o_{i}$ represents the observed number of deaths and $e_{1}$ the expected number of deaths in each area (i) according to the national standard. ${ }^{30}$ These measures of variance have been established, tested and described in more detail in earlier studies. ${ }^{51133}$

As described by Rothman, standardised death rate ratios were calculated by dividing the directly standardised death rate in each area with the national death rate (national death rate standard $=1){ }^{29}$ The level of significance of the divergence from the national standard was analysed using a $\chi^{2}$ test $(\mathrm{df}=1)$. Analyses were only performed if the expected number of deaths was at least five. ${ }^{30}$ Yates's continuity correction was used..$^{30}$ The standardised death rate ratios were calculated for deaths in hospital and deaths outside hospital separately as well as for all deaths irrespective of place of death.

The relationship between death rate ratios for deaths outside hospital and deaths in hospital was tested using Pearson's product-moment correlation. The coefficient of correlation and the level of significance of the correlation was tested.

In order to decide whether the proportion of deaths outside hospital may have an influence on the total death rate, the correlation between the standardised proportion of deaths outside hospital and the standardised death rate ratio for all deaths was also analysed.

For the statistical analyses the Statistical Analysis System (SAS) was used. ${ }^{34}$

\section{Results}

The number of deaths and the mean annual death rate in those aged 0-69 years for selected causes of death are shown in table 2. The results are also grouped as deaths in hospital and deaths outside hospital. The place of death was specified for between 97 and $99 \%$ of the deaths. The highest proportion of deaths outside hospital was found for asthma (58\%) and for ischaemic heart disease $(54 \%)$. The corresponding figure for ulcer of the stomach and duodenum was $44 \%$ and for diabetes it was $31 \%$. For cerebrovascular disease only $16 \%$ of the deaths occurred outside hospital in the age group studied.

The autopsy rate differed for the different causes of death and for different places of death (table 3). In general, the autopsy rates for deaths outside hospital were higher than for those in hospital. For instance, nearly all deaths from ulcer of the stomach outside hospital $(96 \%)$ were followed by necropsy. For cerebro- 
Table 4 The observed and systematic variance in mortality in administrative health areas for selected causes of death in people aged 0-69 years in Sweden between 1987 and 1990

\begin{tabular}{lllll}
\hline ICD-9 code & Cause of death & $\begin{array}{l}\text { Observed } \\
\text { variance }\end{array}$ & $\begin{array}{l}\text { Systematic } \\
\text { variance }\end{array}$ & P value \\
\hline 250 & Diabetes & 0.045 & 0.027 & $<0.001$ \\
$410-414$ & Ischaemic heart disease & 0.015 & 0.014 & $<0.001$ \\
$430-438$ & Cerebrovascular disease & 0.026 & 0.021 & $<0.001$ \\
493 & Asthma & 0.059 & 0.023 & $<0.05$ \\
$531-534$ & Ulcer of stomach and duodenum & 0.094 & 0.039 & $<0.05$ \\
\hline
\end{tabular}

Table 5 The correlation between the standardised death rate ratios* for deaths in hospital and deaths outside hospital for selected causes of death in administrative health areas for people aged 0-69 years in Sweden between 1987 and 1990

\begin{tabular}{llcl}
\hline ICD-9 code & Cause of death & Correlation coefficient & $P$ value \\
\hline 250 & Diabetes & 0.48 & $<0.05$ \\
$410-414$ & Ischaemic heart disease & 0.48 & $<0.05$ \\
$430-438$ & Cerebrovascular disease & 0.57 & $<0.01$ \\
493 & Asthma & -0.02 & NS \\
$531-534$ & Ulcer of stomach and duodenum & 0.06 & NS \\
\hline
\end{tabular}

* Ratio of the standardised death rate in each health area (standardised by age and sex) and the national death rate.

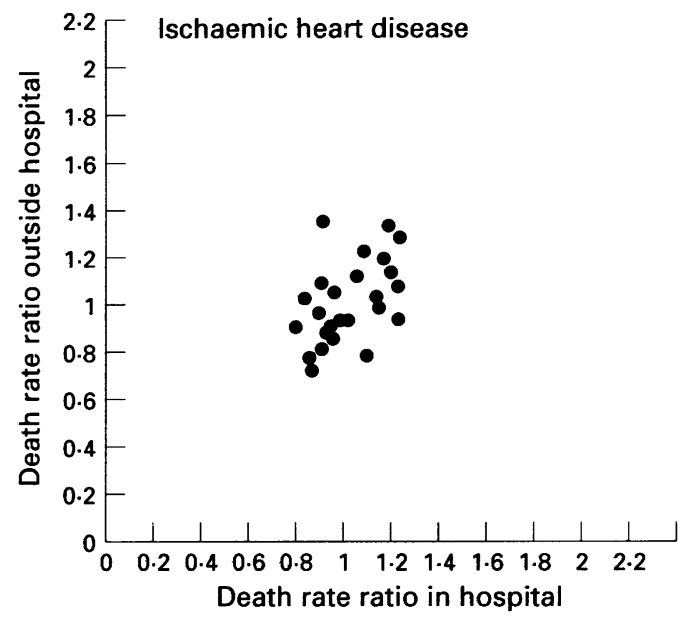

Figure 3 Standardised death rate ratios for ischaemic heart disease deaths in hospital and outside hospital in Swedish administrative health areas for people aged 0-69 years in Sweden between 1987 and 1990. (Standardised by age and sex. National death rate standard $=1$ ).

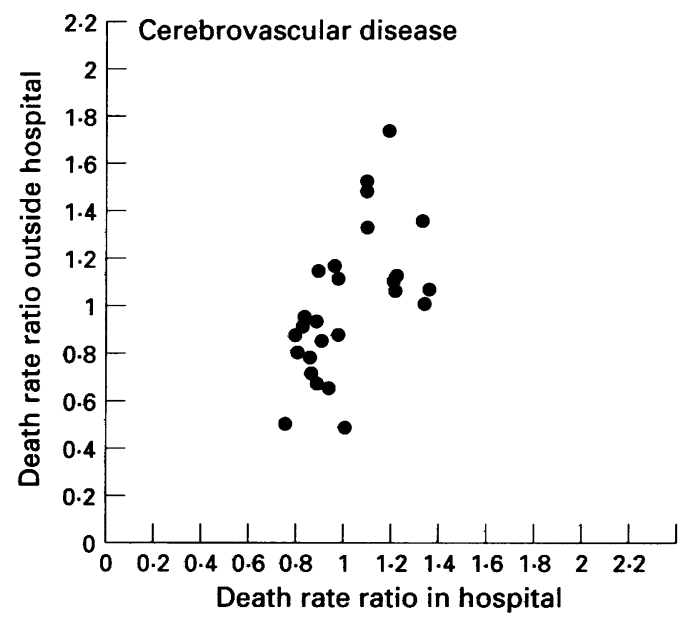

Figure 4 Standandised death rate ratios for cerebrovascular disease deaths in hospital and outside hospital in Swedish administrative health areas for people aged 0-69 years between 1987-1990. (Standardised by age and sex. National death rate standard $=1$ ).

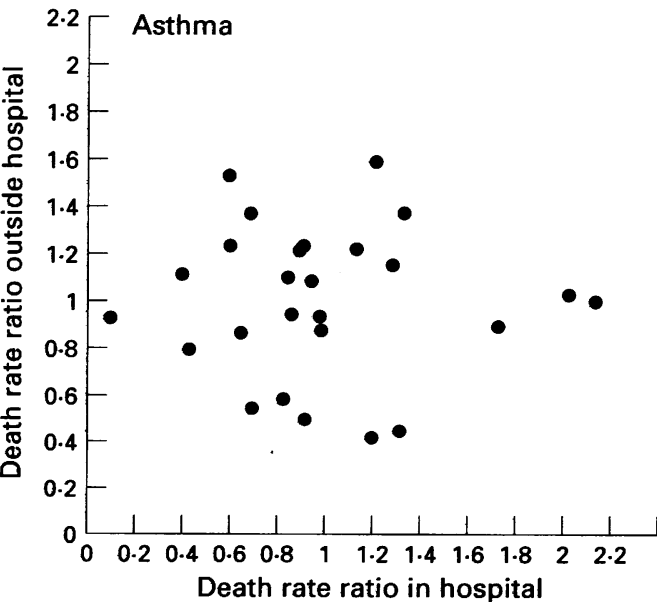

Figure 5 Standardised death rate ratios for asthma deaths in hospital and outside hospital in Swedish administrative health areas for people aged 0-69 years between 1987 and 1990. (Standardised by age and sex. National death rate standard $=1$ ). 


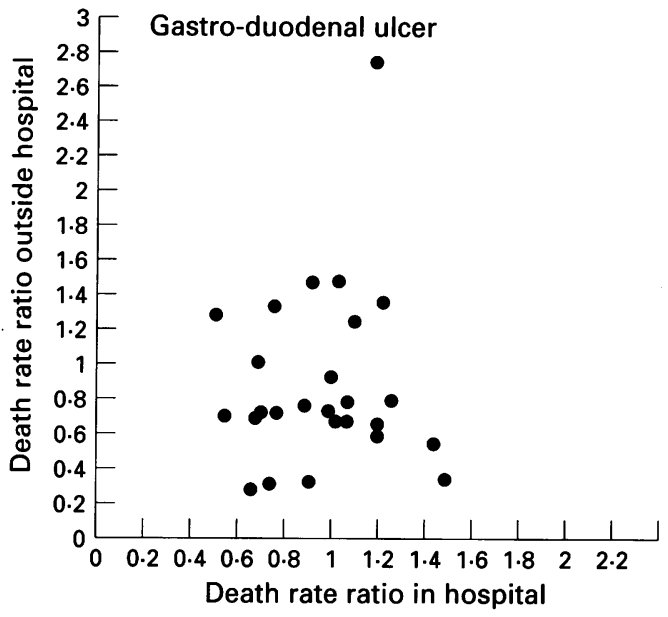

Figure 6 Standardised death rate ratios for gastric and duodenal ulcer deaths in hospital and outside hospital in Swedish administrative health areas for people aged 0-69 years between 1987 and 1990. (Standardised by age and sex. National death rate standard $=1$ ).

the death rates outside hospital corresponded to the death rates in hospital. The level of correlation was, however, modest. The highest correlation coefficient $(0.57)$ was found for cerobrovascular disease. For asthma and ulcer of the stomach and duodenum there was no association between death rates outside hospital and death rates in hospital. To illustrate the correlations for the different selected causes of death, the death rate ratios for deaths outside hospital and deaths in hospital have been plotted in figures 2-6.

Analysis of whether the death rates in the different administrative health areas were as- sociated with the place of death were performed. For each cause of death, the standardised proportion of deaths outside hospital was correlated with mortality, regardless of place of death (table 6). For diabetes and ulcer of the stomach and duodenum, the correlation was significant. Thus, a high death rate was associated with a high proportion of deaths outside hospital while a low death rate was associated with a low proportion of death occurring outside hospital. The correlation, however, was moderate, with a correlation coefficient of $0 \cdot 4$. For ischaemic heart disease cerebrovascular disease, and asthma there was no association between the death rates and the proportion of deaths occurring outside hospital

In table 7 the results for administrative health areas with significantly high total death rates for the selected causes of death are presented. For each area and cause of death the standardised death rate ratios are shown for deaths outside hospital, deaths in hospital, and total deaths irrespective of place of death. For diabetes in the county of Norrbotten the high total mortality was associated with a high rate for deaths outside hospital while the death rate in hospital did not differ from the national standard. For diabetes in the county of Gävleborg, however, a high death rate was found for deaths in hospital. In Norrbotten, causes of death other than diabetes (cerebrovascular disease, asthma) also showed an opposite result with a significantly high rate for deaths in hospital. In the municipality of Göteborg, a high rate was found for deaths from ulcer of the stomach and duodenum outside hospital. This result was associated with a high total mortality for ulcer of the stomach and duodenum in Göteborg.

\section{Discussion}

For asthma and ischaemic heart disease, most deaths in people under 70 years of age occurred outside hospital. The proportion of deaths outside hospital could not, however, explain the variation in death rates among health areas for these causes of death. The high national death rates outside hospital have not previously been pointed out. Some questions on the potential

Table 7 Standardised death rate ratios* for selected causes of death and administrative health areas with significantly high death rates for people aged 0-69 years in Sweden between 1987 and 1990 in relation to place of death

\begin{tabular}{|c|c|c|c|c|c|c|c|c|}
\hline \multirow[t]{2}{*}{$I C D-9$ code } & \multirow[t]{2}{*}{ Cause of death } & \multirow{2}{*}{$\begin{array}{l}\text { Administrative } \\
\text { health area }\end{array}$} & \multicolumn{3}{|c|}{ No. of deaths } & \multirow{2}{*}{$\begin{array}{l}\text { Death rate } \\
\text { ratio total }\end{array}$} & \multirow{2}{*}{$\begin{array}{l}\text { Death rate ratio } \\
\text { at hospital }\end{array}$} & \multirow{2}{*}{$\begin{array}{l}\text { Death rate ratio } \\
\text { outside hospital }\end{array}$} \\
\hline & & & Total & At hospital & Outside hospital & & & \\
\hline \multirow[t]{2}{*}{250} & Diabetes & Gävleborg & 68 & 51 & 16 & $1 \cdot 38^{* *}$ & $1 \cdot 52 *$ & 1.09 \\
\hline & & Norrbotten & 57 & 36 & 21 & $1 \cdot 33^{*}$ & $1 \cdot 24$ & $1 \cdot 60^{*}$ \\
\hline \multirow[t]{2}{*}{$410-414$} & Ischaemic heart disease & Värmland & 1038 & 453 & 565 & $1 \cdot 25^{* * *}$ & $1 \cdot 25^{* * *}$ & $1 \cdot 27^{* * *}$ \\
\hline & & Västerbotten & 836 & 348 & 470 & $1 \cdot 26^{* * *}$ & $1 \cdot 20^{* * *}$ & $1 \cdot 32^{* * *}$ \\
\hline \multirow[t]{5}{*}{$430-438$} & Cerebrovascular disease & Värmland & 213 & 182 & 26 & $1 \cdot 20^{* *}$ & $1 \cdot 22^{* *}$ & $1 \cdot 06$ \\
\hline & & Västmanland & 188 & 149 & 36 & $1 \cdot 26 * *$ & $1 \cdot 19^{*}$ & $1.73^{* *}$ \\
\hline & & Kopparberg & 227 & 200 & 25 & $1 \cdot 30^{* * *}$ & $1 \cdot 36^{* * *}$ & 1.05 \\
\hline & & Västerbotten & 190 & 161 & 27 & $1 \cdot 32^{* * *}$ & $1 \cdot 33^{* * *}$ & $1 \cdot 35$ \\
\hline & & Norrbotten & 187 & 163 & 21 & $1 \cdot 28^{* *}$ & $1 \cdot 34 * * *$ & 1.00 \\
\hline \multirow[t]{2}{*}{493} & Asthma & Malmö & 31 & 10 & 9 & $1.48^{*}$ & $1 \cdot 22$ & 1.58 \\
\hline & & Norrbotten & 32 & 18 & 12 & $1.49 *$ & $2 \cdot 14^{* *}$ & 0.98 \\
\hline \multirow{2}{*}{$531-532$} & $\begin{array}{l}\text { duodenum } \\
\text { ducer or stomach and }\end{array}$ & Stockholm & 102 & 53 & 48 & $1 \cdot 27 *$ & $1 \cdot 22$ & $1 \cdot 36$ \\
\hline & & Göteborg & 45 & 15 & 27 & $1.99^{* * *}$ & $1 \cdot 19$ & $2 \cdot 74 * * *$ \\
\hline
\end{tabular}

* Ratio of the standardised death rate in each health area (standardised by age and sex) and the national death rate. National standard $=1$. Level of significance of the deviance from the national standard:

${ }^{*} \mathrm{p}$ value $<0.05 ;^{* *} \mathrm{p}$ value $<0.01{ }^{* * *} \mathrm{p}$ value $<0 \cdot 001$ 
role of hospital care in the acute phase of disease can be raised for further studies of the quality of care.

For asthma, a high death rate has been found in Sweden compared with other EC countries. ${ }^{35}$ A high proportion of these deaths occurred outside hospital. In studies from other countries of avoidable factors influencing death, deaths outside hospital have been associated with quality of care problems. For instance, a delay in seeking acute help has been found and related to lack of information and family education. ${ }^{1416}$ In another medical audit, several patients who died at home sought medical help only a few days before their death without having their treatment altered. ${ }^{18}$ The high Swedish death rate and the high proportion of deaths outside hospital indicates a need for national medical audits on the quality of care.

For myocardial infarction, deaths may be avoided by earlier arrival at hospital. ${ }^{23}$ Public education in cardiopulmonary resuscitation may also influence survival rates and the number of deaths outside hospital. ${ }^{2436-39}$ In one Swedish health area, a public education campaign was shown to be effective in reducing the treatment delay for heart attack. ${ }^{36-39}$ In this area a low proportion ( $16 \%$ for all ages) of deaths from myocardial infarction occurred outside hospital. ${ }^{36}$ The high national death rate outside hospital begs the question, what could be gained through programmes for earlier treatment of heart attacks? ${ }^{23}$

Cerebrovascular disease has been included as an avoidable death indicator primarily based on the prevention potential but also because of the possibility of treating complications of the disease. $^{2-34041}$ An increased survival has been reported during the last decade, ${ }^{4243}$ which may partly be related to improved supportive hospital care ${ }^{4344}$ as well as to a trend towards less severe strokes. ${ }^{424}$ In this study, most of the cerebrovascular deaths occurred in hospital and no evidence was found that deaths outside hospital could explain the regional variation in mortality.

For diabetes a high death rate in the county of Norrbotten in the north of Sweden was associated with a high rate for deaths outside hospital. Norrbotten is the largest health area and many inhabitants live far from hospital. No general pattern of high death rates outside hospital for the conditions studied was found, however. For diabetes, a review of medical care routine in six counties, among them Norrbotten, showed that a comparatively larger proportion of young patients with diabetes were patients in primary care in the north of Sweden than in the rest of the country. ${ }^{46}$ Whether these patients tried to manage the acute phase of the disease outside hospital to a greater extent is unknown. From the data in this study we cannot infer whether the care was appropriate or not. The results are, however, a warning sign that the chain of events preceding death and the quality of care need to be studied. ${ }^{15}$

The same would be true for ulcers of the stomach and duodenum in the municipality of Göteborg, where the death rate for ulcers was high and where a high rate was observed outside hospital.

When studying regional variation in mortality one should be aware that mortality is an overall and aggregated measure of the outcome of a disease. Data on incidence and/or prevalence and severity of disease would have to be included in order to analyse whether the frequency or case fatality of a disease varies. ${ }^{3347}$

Furthermore, one would have to consider the potential differences in cause of death registration between different areas. The causes of death in persons under 70 years of age have generally been found to be valid in Sweden. ${ }^{2748}$ For chronic diseases, such as diabetes and asthma, the death rates would be higher using multiple causes of death - that is all causes mentioned on the death certificate - when compared with the underlying cause of death. ${ }^{49-51}$ An earlier study has, however, shown that this does not influence the regional variation. Areas with higher death rates than the national standard using underlying causes of death also showed the same result when multiple causes of death were used. ${ }^{51}$

The validity of the cause of death for deaths outside hospital may theoretically be more uncertain since physicians may not follow and register events in the last period of life. A study from Oxford showed that for some conditions, among them diabetes, asthma, and peptic ulcer, death certificates in a significant number of cases did not mention these conditions when death occurred four weeks or one year after admission to hospital. ${ }^{52}$ The Swedish autopsy rates outside hospital were, however, higher than those in hospital, which may increase validity of the causes of death for deaths outside hospital. ${ }^{53}$

Several reports have emphasised the role of the autopsy in modern medical care. There has, however, been a decline in the autopsy rate in Sweden as well as in many countries during the last decades. ${ }^{545}$ One of the functions of the autopsy is to ensure the accuracy of death certificates. Considerable discrepancies have been shown between clinical diagnosis and autopsy diagnosis. ${ }^{4535657}$ For acute myocardial infarction and peptic ulcer, the discrepancy has mainly been low sensitivity of the clinical diagnosis when compared with the autopsy findings. ${ }^{5657}$ In a study from a Swedish university hospital in the late $1980 \mathrm{~s}$, these conditions were diagnosed at autopsy in only about half of the autopsied cases. ${ }^{57}$ The autopsy rate in that study was $38 \%$. Hypothetically, more cases of myocardial infarction and peptic ulcer may have been detected if more autopsies had been performed. One cannot, however, be sure that a higher autopsy rate would increase the death rates for these conditions. The autopsied cases may be selective, reflecting deaths in which the clinical diagnosis was especially uncertain. ${ }^{5758}$ This is in accordance with the Swedish law which states that an autopsy must be performed when the cause of death is unclear. ${ }^{59}$ In this study the autopsy rate was lower for death at hospital than for death outside hospital. Further studies would be needed to decide whether the autopsy rates systematically 
influence the observed death rates for different causes and places of death. ${ }^{60}$

According to the concept of avoidable mortality, high area death rates are warning signals indicating that in-depth studies on the quality of care are needed. ${ }^{15}$ These in-depth studies should also include analyses of the appropriateness of death certificates. ${ }^{560}$

This study was limited to five common causes of death for which the acute management at hospital may be of importance. In most cases, no evidence was found that the proportion of deaths outside hospital had influenced the regional variation in mortality. For ulcers of the stomach and duodenum in the municipality of Göteborg and for diabetes in the Norrbotten area, however, high death rates were associated with a high proportion of deaths outside hospital suggesting further studies on the quality of care are needed.

The author would like to thank colleagues at the Departmen of Social Medicine, Uppsala for their comments. The study was supported by a grant from the Swedish Society of Medicine.

1 Rutstein DD, Berenberger W, Chalmers TC, Child GC Fischmen AP, Perrin EB. Measuring the quality of medica care. $N$ Engl f Med 1976;294:582-8.

2 Holland WW ed. European Community atlas of avoidable death. Commission of the European Communities Health death. Commission of the European Commun

3 Holland WW ed. European Community atlas of "avoidable death". Second edition. Volume one. Commission of the death". Second edition. Volume one. Commission of the European Communities Health Services Res
No. 6. Oxford Medical Publications 1991.

4 Mackenbach JP, Bouvier-Colle MH, Jougla E. "Avoidable" mortality and health services: a review of aggregate data studies. $\mathcal{F}$ Epidemiol Community Health 1990;44:106-11.

5 Westerling R. The "avoidable" mortality method. Empirical studies using data from Sweden. Department of Social Medicine. Uppsala University 1993. (Thesis)

6 Charlton JRH, Hartley RM, Silver R, Holland WW. Geographical variation in mortality from conditions amenable to medical interventions in England and Wales. Lancet 1983;i:691-6.

7 Charlton JRH, Lakhani A, Aristidou M. How have "avoidable death" indices for England and Wales changed? 1974-78 compared with 1979-83. Community Medicin 1974-78 compared

8 Juel K, Kamper-Jørgensen F. Undgåelige dødsfald i Danmark 1970-1983. Variation med sygehuskommune o periode. Ugeskrift for Laeger 1986;148:1981-5.

9 Mackenbach JP, Kunst AE, Looman CWN, Habbema JDF, van der Maas PJ. Regional differences in mortality from conditions amenable to medical intervention in The Neth erlands: a comparison of four time periods. $\mathcal{F}$ Epidemio Community Health 1988;42:325-32.

10 Mackenbach JP, Looman CWN, Kunst AE, Habbema JDF van der Maas PJ. Regional differences in decline of mortality from selected conditions: the Netherlands, 1969 1984. Int f Epidemiol 1988;17:821-7.

11 Westerling R. Indicators of "avoidable" mortality in health administrative areas in Sweden 1974-1985. Scand f Soc Med 1993;21:176-87.

12 Pampalon R. Avoidable mortality in Quebec and its regions. Soc Sci Med 1993;37:823-831.

13 Rea HH et al. Lessons from the national asthma mortality study: circumstances surrounding death. $N Z M e d F 1987$ 100:10-13

14 Sutherland DC, Beaglehole R, Fenwick J, Jackson RT, Mullins P, Rea HH. Deaths from asthma in Auckland: circumstances and validation of causes. $N Z$ Med $\mathcal{F} 1984$ 97:845-848.

15 Fletcher HJ, Ibrahim SA, Speight N. Survey of asthma deaths in the northern region 1970-85. Arch Dis Child 1990;65:163-67.

16 Robertson CF, Rubinfield AR, Bowes G. Deaths from asthma in Victoria: a 12-month survey. Med $\mathcal{F}$ Aust 1990, 152:511-7.

17 Robertson CF, Rubinfield AR, Bowes G. Pediatric asthma deaths in Victoria: the mild are at risk. Pediatric Pulmonology 1992;13:95-100.

18 Ormerod LP. Asthma mortality in Birmingham 1975-7: 53 deaths. $B M \mathcal{Y}$ 1980;280:687-90.

19 Connell FA, Louden JM. Diabetes mortality in persons under 45 years of age, Am 7 Public Health 1983;73:117477.

20 Scibilia J, Finegold D, Dorman J, Becker D, Drash A Why do children with diabetes die? Acta Endocrinol 1986 279(suppl):326-33.

21 Svanes C, Lie RT, Svanes K, Lie SA, Söreide O. Adverse effects of delayed treatment for perforated peptic ulcer. Ann Surg 1994;220:168-75.

22 Walker DM, Wicke $M$, Hubbard WN, Thomas RD. In- creased mortality from inadequate provision of coronary care unit facilities. $\mathcal{F} R$ Soc Med 1994;87:211-12

23 Heller RF, Alexander HM, Dobson AJ, Steele PL, Malcolm JA, Al-Roomi KA. Death from myocardial infarction: what are the benefits of early arrival at hospital and thrombolysis? Med 7 Aust 1990;152:301-4.

24 Cummins RO, Ornato JP, Thics WH, Pepe PE. Improving survival from sudden cardiac arrest: the chain of survival concept. A statement for health professionals from the advanced cardiac life support subcommittee and the emergency cardiac care committee, American Heart Association. AHA medical/scientific statement. State-of-theArt review. Circulation 1991;83:1832-47.

25 Hobbs MST, Jamrozik KD, Hockey RL, et al. Mortality from coronary heart disease and incidence of acute myocardial infarction in Auckland, Newcastle and Perth. Med $\mathcal{F}$ Aust 1991;7:436-42.

26 World Health Organization. International statistical classification of diseases, injuries and causes of death. 9th rev. Geneva: WHO, 1977.

27 Dödsorsaker (Causes of death). Stockholm: National Central Bureau of Statistics, 1987-1990. (Yearly Report) (In Swedish: summary in English).

28 Befolkningsförändringar (Population changes). Stockholm: Na tional Central Bureau of Statistics 1987-1990. (Yearly Report) (In Swedish)

29 Rothman KJ. Modern Epidemiology. Boston: Little Brown and Company, 1986.

30 Armitage P, Berry G. Statistical methods in medical research 2nd ed. Oxford and Edinburgh: Blackwell Scientific Publications, 1987.

31 Diehr P, Cain K, Conell F, Volinn E. What is too much variation? The null hypothesis in small-area analysis. Health Services Res 1990;24:741-71.

$32 \mathrm{McPherson} \mathrm{K}$, Wennberg JE, Hovind OB, Clifford P. Small area variations in the use of common surgical procedures: an international comparison of New England, England, and Norway. $N$ Engl $\mathcal{F}$ Med 1982;18:1310-14.

33 Westerling $\mathbf{R}$. Components of small area variation in death rates - a method applied to data from Sweden. 7 Epidemio Community Health 1995;49:214-21.

34 SAS Institute Inc. SAS user's guide: statistics. Version 5 Editions. Cary, NC: SAS Institute Inc, 1985.

35 Westerling R, Smedby B. The European Community "avoidable death indicators" in Sweden 1974-1985. Int $f$ Epidemiol 1992;21:502-10.

36 Herlitz J, Karlsson BW, Hjalmarson $\AA$. Causes of death in patients presenting to hospital with symptoms suggestive of acute myocardial infarction: a one-year follow-up study with autopsy results. Coronary Artery Disease 1994;5:5160 .

37 Herlitz J, Hartford M, Blohm M, et al. Effect of a media campaign on delay times and ambulance use in suspected acute myocardial infarction. Am f Cardiol 1989;64:90-3.

38 Blohm M, Herlitz J, Schröder U, et al. Reaction to a media campaign focusing on delay in acute myocardial infarction. Heart Lung 1991;20:661-6.

39 Herlitz J, Hartford M, Karlsson BV, Risenfors M, Blohm M, Leupker RV, Wennerblom B, Holmberg S. Effect of a media campaign to reduce delay times for acute myocardial infarction on the burden of chest pain patients in the emergency department. Cardiology 1991;79:127-34.

40 Oppenheimer S, Hackinski V. Complications of acute stroke. Lancet 1992;339:721-4.

41 Arboix A, Massons J, Oliveres M, Garcia L, Titus F. Mortality in the acute phase of cerebrovascular disease registry of the Central La-Alianza-Hospital in Barcelona. Medicina Clinica 1994;103:529-33.

42 Stegmayr B, Asplund K, Wester PO. Trends in incidence, case-fatality rate, and severity of stroke in northern Sweden, 1985-1991. Stroke 1994;25:1738-45.

43 Shahar E, McGovern PG, Sprafka JM, Pankow JS, Dolisz ney KM, Leupker RV, Blackburn H. Improved surviva of stroke patients during the $1980 \mathrm{~s}$ - the Minnesota strok survey. Stroke 1995;26:1-6.

44 Langhorne P, Williams BO, Gilchrist W, Howie K. Do stroke units save lives? Lancet 1993;342:395-8.

45 Wolf PA, Dáugostina RB, O’Neal MA, Sytkowski P, Kase CS, Belanger AJ, Kannel WB. Secular trends in stroke incidence and mortality: The Framingham study. Stroke 1992;23:1551-5.

46 Östman J, Larsson Y, Adamsson U, Ericsson A, Nilsson B, Wredling $R$. Diabetesvården granskad i åtta län. Sverige på väg mot Europamålet. (Diabetes care audit in eight pa vang mot Europamalet. (Diabetes care audit in eight Swedish). Läkartidningen 1995;92:1483-6.

47 Wolfe CDA, Taub NA, Woodrow J, Richardson E, Warburtons FG, Burney PGJ. Does the incidence, severity, or case fatality of stroke vary in southern England? Epidemiol Community Health 1993;47:139-43.

48 Britton M. Diagnostic errors discovered at autopsy. Acto Med Scand 1974;196:203-10.

49 Fuller JH, Goldblatt P, Adelstein AM. Diabetes mortality: new light on an underestimated public health problem. Diabetologia 1983;24:336-41.

50 Israel AI, Rosenberg HM, Curtin LR. Analytical potentia for multiple cause-of-death data. Am $\mathcal{F}$ Epidemiol 1986; 124:161-79.

51 Westerling R. Small-area variation in multiple causes of death for certain chronic conditions in Sweden - a comparison with underlying causes of death. Int 7 Epidemiol 1995;24:552-8.

52 Goldacre MJ. Cause-specific mortality: understanding un- 
certain tips of the disease iceberg. I Epidemiol Community Health 1993;47:491-6.

53 Riboli E, Delendi M eds. Autopsy in epidemiology and medical research. Lyon: WHO 1991. IARC Scientific Publications No 112

54 Landefeld CS, Chren MM, Myers A, Geller R, Robbins S Goldman L. Diagnostic yield of the autopsy in a university hospital and a community hospital. New Engl f Med 1988; 318:1249 and

55 Eriksson L, Sundström C. Decreasing autopsy rate in Sweden reflects changing attitudes among clinicians. Quality Assurance in Health Care 1993;5:319-23.

56 Andersson RE, Hill RB, Key CR. The sensitivity and speci- ficity of clinical diagnostics during five decades. Towards an understanding of necessary fallibility. $\mathcal{F} A M A 1989 ; 261$ $1610-17$

57 Veress B, Alafuzoff I. Clinical diagnostic accuracy audited by autopsy in a university hospital in two eras. Quality Assurance in Health Care 1993;5:281-6.

58 Saracci $R$. Is necropsy a valid monitor of clinical diagnosis performance? BMf 1991;303:898-900

59 obduktionslagen (The autopsy act; in Swedish). Stockholm: 1975:191.

60 Charlton JRH, Bauer R, Lakhani A. Outcome measures for district and regional health care planners. Community Medicine 1984;6:306-15. 